\title{
Labeling and Interpersonal Relationship of Negatively-Labeled Students in Physics
}

\author{
Beryl John P. Conejar, Carl Francis E. Endoma, \\ Shiere Diadem R. Lagarto and Jessa Marie L. Layog \\ An Undergraduate Thesis, Bachelor of Secondary Education, \\ West Visayas State University, Iloilo City, Philippines (2015) \\ beryconejar@gmail.com
}

\begin{abstract}
This qualitative study primarily aimed to determine the relationship between labeling and interpersonal relationship of negatively-labeled students in physics. Specifically it aimed to answer the following questions: (1) Does the family background of the respondents affect their interpersonal relationships between other students and the physics teacher?; (2) What is the relationship of the negatively-labeled students towards their classmates and Physics teacher? (3) How does labeling affect a student inside a Physics class?; and (4) How do the negativelylabeled students deal with labeling? Two (2) negatively labeled students were selected during class observations and through the recommendation of the subject teacher. The participants were selected based on the following qualifications: (1) a fourth year student taking up Physics as a subject; (2) has experienced negative labeling; (3) willing to participate in the study. Permit to conduct the study was secured from the principal who referred the researchers to a physics teacher of the $4^{\text {th }}$ year students. Class observations were conducted followed by an indepth interview of the subjects of the study. The whole conversation was video recorded for transcription and further analysis of data. The subjects' facial expressions and gestures were also noted. The results of this study were based on two resources, namely; "ecomap", as supported by Bronfenbrenner's Ecological System Theory and in-depth interview. The respondents were asked to draw the ecomap with the guidance of the researchers. The data were interpreted based on the guidelines. A semi-structured interview guideline was prepared prior to the interview. The statements were transcribed and analyzed using the grounded theory method. This study has found out that: (1) Family backgrounds affects the interpersonal relationships of negatively labeled students with peers and physics teacher; (2)Negativelylabeled students have a positive relationship toward their classmates and physics teacher except for those classmates who labeled them; (3) Negatively-labeled students experience a degraded self-esteem because of frequent humiliation and ridicule by their classmates in a physics class; (4) Dealing with labeling depends upon the personal outlook of the affected individual. Dealing with labelling depends upon the outlook of an individual. It was also found out that students were negatively-labelled because of their personal attitudes, behaviour inside the classroom, personal issues or conflicts with their peers and academic performance. In the context of this study, the following themes emerged: Negatively labelled students experienced a degraded self-esteem because of frequent humiliation and ridicule by their classmates in a physics class, but dealing with labeling depends upon the personal outlook of the affected individual.
\end{abstract}

Keywords: Ecomap, Interpersonal relationship, Labeling, Physics, Stigma 


\section{Introduction}

The impact of academic labeling displays itself in extraordinary differences that exist in our educational system (Woolfolk, 2007). Furthermore, the labels given to the students, even if they are positive, such as "bright" or "smart", embolden the labeled students to practice what is expected of them. Comparably, students who are negatively labeled as "dull" or "stupid" will work to reach the limited expectations that others have of them, thereby performing at inferior levels in both social and academic setting.

"Labeling" as stated by Woolfolk (2007) is a controversial issue. It has been undergoing much research in the field of education to find out the academic performance of students based on the labels given to them in the class. "Everyone - teachers, parents, and classmates, and even students themselves may see a label as a stigma that cannot be changed" (Woolfolk, 2007). For one thing, the society explains the behavior of an individual in terms of the labels attached to him (Woolfolk, 2007).

According to academic researcher Ray C. Rist, within the framework of labeling theory, a major emphasis has been placed upon the role of [academic] institutions in sorting, labeling, tracking, and channeling persons along various routes depending upon the assessment the institution has made of the individual. In other words, the classification and labeling among students in schools play an increasingly significant role in determining students' progress and academic success.

Furthermore, he added that only through exploring the extent of the possible limitations and benefits that academic labeling causes can one truly understand why administrators and teachers, as "labelers" who alone come to possess the authority to provide certification for credentials of labeling students, tremendously affect their students' futures in ways that can be either negative or positive.

The use of ecomap is one way of determining how labeling affects or cause changes to the students. According to Hartman (cited in Calix, 2004), ecomap is a paper-and-pencil simulation that maps the ecological system whose boundaries encompass the individual or family. It is a graphical representation that demonstrates all of the systems at play in an individual's life. They are commonly used in individual and family counseling.

Many students have experienced to be labeled which undeniably created an observable change in them, like in their attitude towards their studies, behavior and their social interaction. According to Batan et al., (2010), despite the inevitability of labeling, researchers in education mostly focus on the effects of labeling to those who are considered exceptional. These accounts captured the interests of the researchers to study labeling.

\section{Content of the Study}

\subsection{Paradigm of the Study}

Independent Variable

Dependent Variable

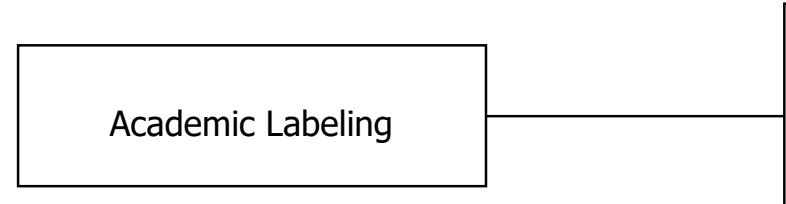

Interpersonal Relationship between Other Students and the Physics Teacher

Figure 1. The Research Paradigm showing the Relationship between the Independent Variable and the Dependent Variables 


\subsection{Statement of the Problem}

This study generally aims to determine the relationship between labeling and interpersonal relationship of negatively-labeled students in Physics. Specifically, it aims to answer the following questions:

1. Does the family background of the respondents affect their interpersonal relationships between other students and the Physics teacher?

2. What is the relationship of the negatively-labeled students towards their classmates and Physics teacher?

3. How does labeling affect a student inside a Physics class?

4. How do the negatively-labeled students deal with labeling?

\subsection{Assumption}

There is a significant connection between labeling and the interpersonal relationship of negatively-labeled students between other students and their physics teacher.

\subsection{Delimitation of the Study}

This study included two negatively-labeled students in a physics class in a public school in Iloilo, Philippines it was conducted on October 7, 2014 and November 20, 2014.

The participants were chosen through class observations and through the recommendation of the subject teacher. The data were gathered through eco-mapping. Students were made to draw a sketch of their interpersonal relationship between other students and their physics teacher with the assistance of the researchers. The data drawn from the eco-maps were interpreted and analyzed through qualitative data analysis. An in-depth interview with the two respondents was also conducted. The interview was recorded as a video file and was transcribed and analyzed using the grounded theory methodology.

The information collected from the participants' point of view were focused on determining how labeling affects the interpersonal relationship of negatively-labeled students with other students and their subject teacher in physics.

\subsection{Research Design}

This research is intended to find out the interpersonal relationship of negatively-labeled students between other students and the physics teacher. The respondents were two 4th year high school students of a school in Iloilo, Philippines.

Qualitative research design was utilized in this study. Qualitative research is an umbrella term for a broad range of approaches and methods, which vary considerably in terms of focus, assumptions about the nature of knowledge and the role of the researcher. According to the University of Southern California (2014), qualitative researchers stress the socially constructed nature of reality, the intimate relationship between the researcher and what is studied, and the situational constraints that shape inquiry. Furthermore, such researchers emphasize the valueladen nature of inquiry and they seek answers to questions that stress how social experience is created and given meaning.

\section{Methodology}

\subsection{The Research Participants}

Two negatively-labeled students were selected during class observations and through the recommendation of the subject teacher. The participants were selected based on the following 
qualification: a fourth year student taking up Physics as a subject who experiences negative labeling and is willing to participate in the study.

\subsection{Research Instruments}

The results of this study were based on two sources namely: ecomap as supported by Bronfenbrenner's Ecological System Theory and in-depth interview.

The ecomaps are diagrams that depict an individual or a family within a societal context, demonstrating the energy, supports, and resources necessary to maintain specific relationships. (Aeby, Aeby \& Boyd, 2007). The respondents were asked to draw the ecomap as guided by the researchers. The data were interpreted based on the guidelines. Bronfenbrenner's Ecological Systems Theory was also utilized to support the findings of the ecomap.

A semi-structure interview guideline was prepared prior to the conduct of interview. The answers of each respondent were recorded using a video recording device to facilitate further interpretation. The statements were transcribed and analyzed using the grounded theory method.

\subsection{Data Collecting Procedure}

Permit to conduct the study was secured from the school principal who referred the researchers to a Physics teacher of the fourth year students. Class observations were conducted followed by an in-depth interview of the subjects of the study. The whole conversations were video-recorded for transcription and further analysis of data. The subjects' facial expression and gestures were also noted.

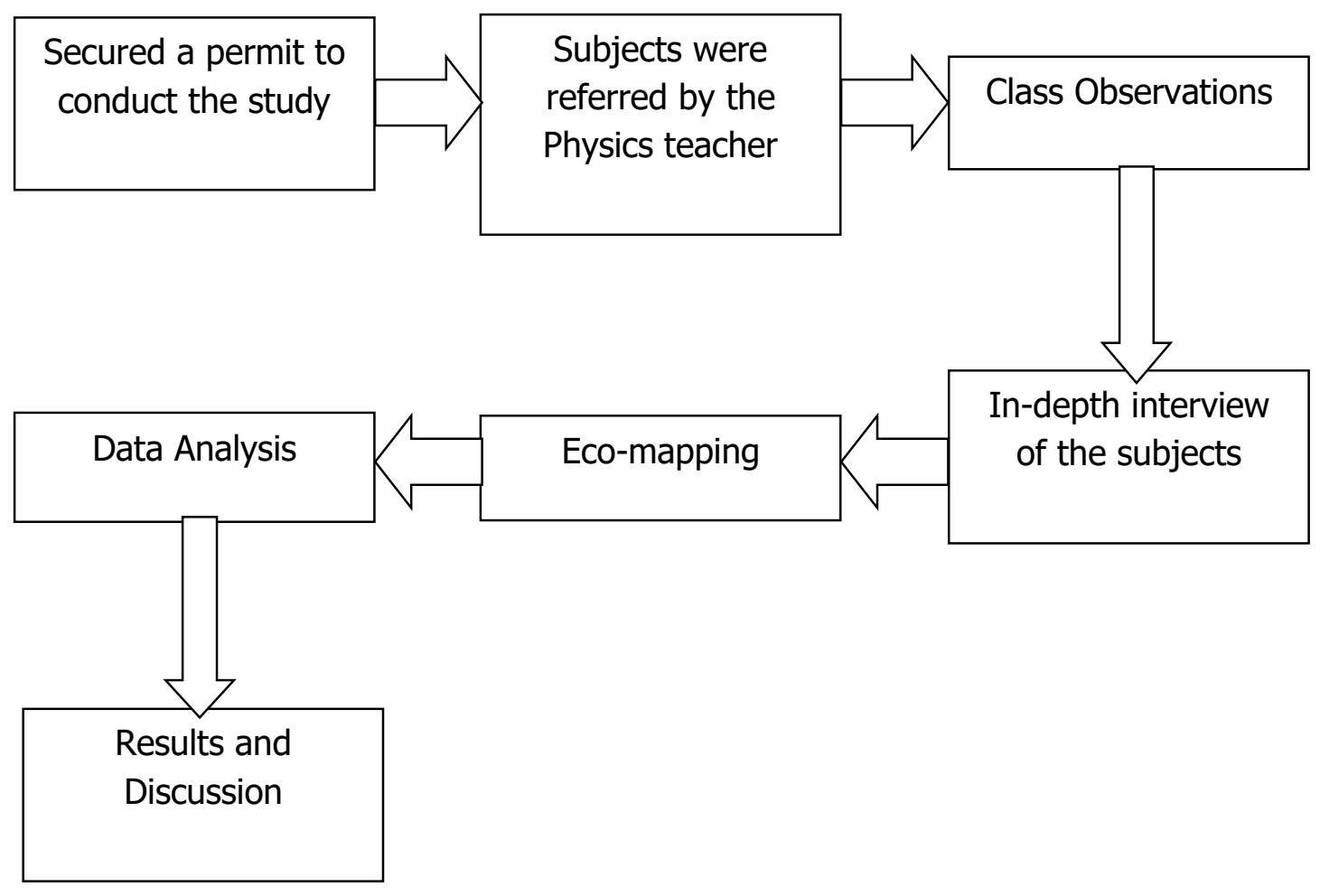

Figure 2. Steps in Conducting the Study 


\section{Data Analysis}

\subsection{Ecomap}

The ecomap was drawn by the subjects with guidance of the researchers.

The eco-maps were constructed from the subjects' own perspective without family or peer involvement. The ecomap provides a unique method to organize and present concurrently factual information and the relationships between variables in the family's current ecology. To determine the strength of relationships of the subjects to their family members, peers and the Physics teacher, a legend was provided for them to sketch the most appropriate line which indicate the present status of their relationships with the persons mentioned.

The researchers sit with subjects and introduced the activity as a way of identifying the subjects' relationships between family members, peers and the Physics teacher. The process began by putting a circle in the middle of the page with the subject's name in it. The ecomap was designed using circles to denote the persons involved. Lines are drawn connecting the circles that depict the quality of the relationships between the connections. Straight, fine lines were used to indicate good connections; Straight, bold lines were used to indicate strong connections; dashed lines signify negative relationships; crooked lines over a fine line signified stressful relationships.

The ecomap takes into account Bronfenbrenner's model of the ecology of human development consisting of four concentric ecological subsystems: microsystem, mesosystem, exosystem, and macrosystem. Furthermore, the ecomap organizes meso-level (networks of personal settings in which we live our lives) and exo-level (the larger institutions of society that influence our personal systems) environmental contingencies that are involved in the ecosystem of the client. Micro level information, or face-to-face direct contact, is provided in the interactional assessment. The macro level influence that represents the larger sub-cultural and cultural contexts is also seen using this assessment. The data using Bronfenbrenner's model of the ecology of human development were presented in tabular form in Chapter 4 of this study.

\subsection{In-Depth Interview}

During the in-depth interview, the researchers asked particular questions to the respondents aligned with the study. The questions were prepared by the researchers prior to the conduct of interview. The semi-structure interview questions were divided into two categories: (1) How labeling inside the classroom affects a student and (2) Dealing with labeling. The first category involves questions like "What label or "bad names" did they use on you?", "In what instances does your teacher, friends or classmates usually call you this way?" and How did the labeling affect your performance, perceptions and response in your Physics subject?". In the second category, dealing with labeling, questions like: "How do you react whenever you were labeled a "bad name"?", "How did you deal with the situation when you were labeled or called that way?", and "Will you do the same to others? Will you also call them bad names?".

The answers of each respondent were recorded using a recording device for further interpretation. The statements were transcribed and analyzed using the transcription convention and grounded theory methodology (GTM). 


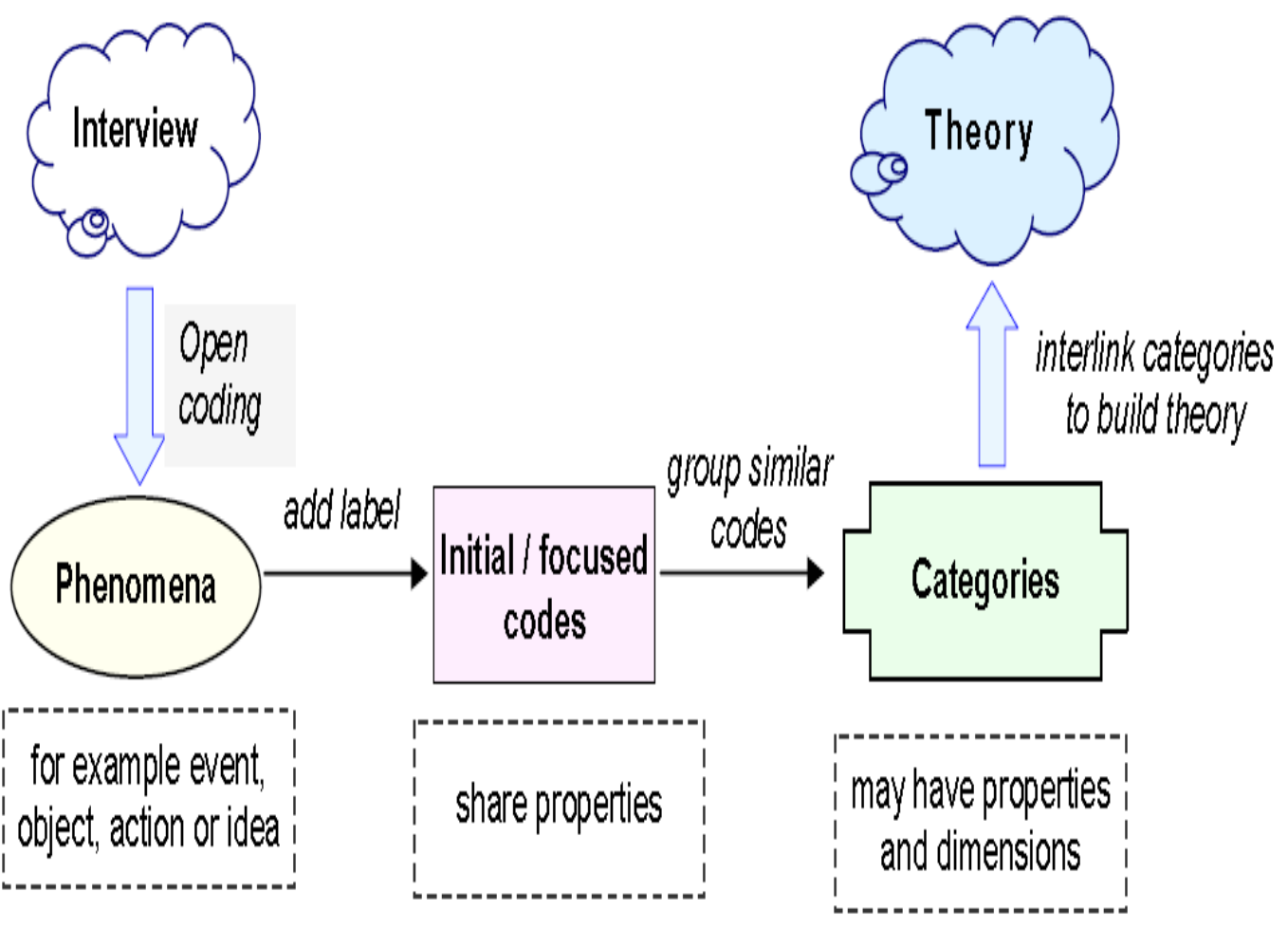

Figure 3. Coding Steps in Grounded Theory (2005)

\subsection{Utilizing the Grounded Theory Methodology}

For this study, open coding was used for the preliminary part of the analysis followed by the focused coding. Axial coding was not used in this study because the method of specifying properties and dimensions for each category seemed too prescriptive and did not help the analysis of the data. For the same reasons, theoretical coding was not adopted. Instead, careful comparisons between respondents' statements, as well as between codes and categories were undertaken, without being restricted to interpret participants' words within a framework of properties and dimensions. Coding was done after the data gathering process. As codes and categories were identified, the research team compared and contrasted new data-to-data implications that was collected previously and this analysis of emerging themes, patterns, and relationships between categories provided the grounding to build theory.

A grounded theory is directly related to the data from which it has been generated; it is therefore grounded in the data. Codes were used to come up with an emerging theme. In the context of this study, the results were based on emerging themes. 


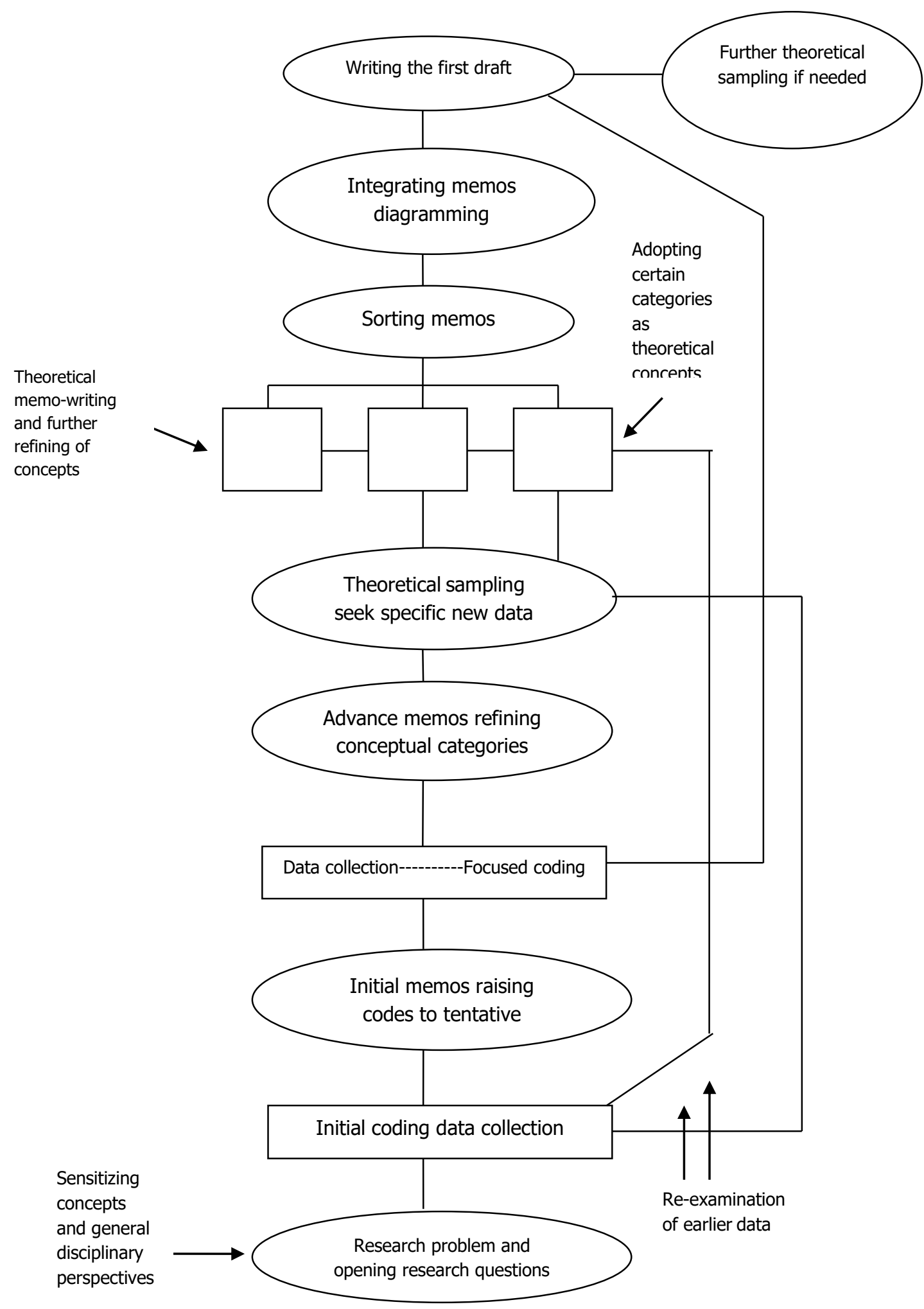

Figure 4. The Grounded Theory Process 


\section{The Experimental Process}

\subsection{Interpersonal Relationships}

\section{Bronfenbrenner's Ecological Systems Theory}

Interpersonal Relationships through Bronfenbrenner's Ecological Systems Theory and Ecomapping Bronfenbrenner believed that a person's development was affected by everything in their surrounding environment. The data presented on the table was obtained through interview. The questions served as a guide which are categorized based on Bronfenbrenner's Ecological Systems Theory.

In the microsystem level, the respondents were asked about their closest environment specifically about their personal habits and relationships especially with their parents. Based on their responses, as shown in table 4, both of them are engaged in sports. Their spiritual lives were not so active for they seldom go to church. There was a great difference in terms of their relationships with their parents. John* was very close to both of his parents while Lea*, knowing that she has a broken family and she is living with her mother's family, was not too close to them. When they were asked if they eat together as one family, John* answered that they seldom do it. Lea* who lives with her grandparents answered that they do eat together.

Table 1. Microsystem

\begin{tabular}{|l|l|l|}
\hline \multirow{2}{*}{ Questions } & \multicolumn{2}{c|}{ Answers } \\
\cline { 2 - 3 } & Respondent 1(John*) & \multicolumn{1}{c|}{$\begin{array}{c}\text { Respondent 2 } \\
\left(\text { Lea }^{*}\right)\end{array}$} \\
\hline 1. Do you engage in active games? & Yes & Yes \\
\hline $\begin{array}{l}\text { 2. Do you prefer to eat healthy foods (e.g. } \\
\text { vegetables and fruits)? }\end{array}$ & Yes & Yes \\
\hline 3. Do you pray and go to church? & Sometimes & Sometimes \\
\hline 4. Are you close with both of your parents? & Yes & $\begin{array}{l}\text { Not close to mother } \\
\text { Not recognized by her father }\end{array}$ \\
\hline 5. Do you eat together with the whole family? & Sometimes & Yes (with grandparents) \\
\hline
\end{tabular}

The microsystem is the layer closest to the child and contains the structures with which the child has direct contact (Ryan, 2001). The microsystem encompasses the relationships and interactions a child has with her immediate surroundings (Berk cited in Paquette \& Ryan, 2001).

The data in Table 2 reveal that the parents don't have an idea of who the friends of their child are because possibly, their friends visit their homes occasionally. John* performs his tasks at home while Leah* only do them if she is told to do so. The parents of John* are aware of his involvement in sports which is a total opposite for Lea* for her parents were not living with her. 
Table 2. Mesosystem

\begin{tabular}{|c|c|c|}
\hline \multirow[b]{2}{*}{ Questions } & \multicolumn{2}{|c|}{ Answers } \\
\hline & $\begin{array}{c}\text { Respondent } 1 \\
(\text { John*) }\end{array}$ & $\begin{array}{c}\text { Respondent } 2 \\
(\text { Lea*) }\end{array}$ \\
\hline $\begin{array}{l}\text { 1. Parents don't know the } \\
\text { friends of their child. }\end{array}$ & Not all & No \\
\hline $\begin{array}{l}\text { 2. The friends of the child } \\
\text { visit their home. }\end{array}$ & Sometimes & Sometimes \\
\hline $\begin{array}{l}\text { 3. The child do his or her } \\
\text { household chores. }\end{array}$ & Yes & If told to do so. \\
\hline $\begin{array}{l}\text { 4. The parents know the } \\
\text { game of their child. }\end{array}$ & Yes & No \\
\hline
\end{tabular}

The mesosystem layer provides the connection between the structures of the child's microsystem (Berk cited in Paquette \& Ryan, 2001). Examples: the connection between the child's teacher and his parents, between his church and his neighborhood, etc.

As shown in table 3, both of *John's parents have work but in the case of *Lea, only her mother have work. In terms of family ties, John* does leisure time with his family while in Lea's * case she spends it with her grandparents. They are both active in school for they are joining school activities like sports which is part of their extra-curricular activities. John* lives in a quiet place which is in opposite with Lea*. The parents of John* do manage their emotions sometimes while the grandparents of Lea* can control emotions.

Table 3. Exosystem

\begin{tabular}{|c|c|c|}
\hline \multirow{2}{*}{ Questions } & \multicolumn{2}{|c|}{ Answers } \\
\hline & $\begin{array}{l}\text { Respondent } 1 \\
\text { (John*) }\end{array}$ & $\begin{array}{l}\text { Respondent } 2 \\
\left(\text { Lea }{ }^{*}\right)\end{array}$ \\
\hline 1. Do your parents have work? & $\begin{array}{l}\text { Both parents are } \\
\text { working }\end{array}$ & $\begin{array}{l}\text { Only the mother has } \\
\text { work }\end{array}$ \\
\hline $\begin{array}{l}\text { 2. Does your family watch television } \\
\text { or go to the mall during their leisure } \\
\text { time? }\end{array}$ & Yes & $\begin{array}{l}\text { Yes (with } \\
\text { grandparents) }\end{array}$ \\
\hline 3. Do you join in school activities? & Yes & Yes \\
\hline 4. Do you live in a quiet place? & Yes & No \\
\hline $\begin{array}{l}\text { 5. Do your parents manage their } \\
\text { emotions in front of you? }\end{array}$ & Sometimes & $\begin{array}{l}\text { Yes (refers to } \\
\text { grandparents) }\end{array}$ \\
\hline
\end{tabular}

This level encompasses the larger institutions of society that influence our personal systems. The respondents were interviewed with questions based on this level.

The fourth level of ecological systems theory is the macrosystem which encompasses the cultural environment in which the person lives and all other systems that affect them (Roundy, 2014). When the respondents were asked if they were taught with good values with their 
parents, they both answered yes. They also revealed that their parents are following some superstitious beliefs. The data are shown in Table 4.

Table 4. Macrosystem

\begin{tabular}{|l|l|l|}
\hline \multirow{2}{*}{\multicolumn{1}{|c|}{ Questions }} & \multicolumn{2}{c|}{ Answers } \\
\cline { 2 - 4 } & \multicolumn{1}{|c|}{\begin{tabular}{c}
\multicolumn{2}{c|}{ Respondent 1 } \\
$($ John*)
\end{tabular}} \\
(Lea*)
\end{tabular}

\section{Eco-mapping}

In the literature, conducting an ecosystem assessment allows the practitioner to gather data on mutually interacting environmental systems (Calix, 2004).The genogram, which is encompassed within the ecomap, organizes the historical and developmental data that may influence present interactions. The ecomap takes into account Bronfenbrenner's model of the ecology of human development consisting of four concentric ecological subsystems: microsystem, mesosystem, exosystem, and macrosystem (Bronfenbrenner cited in Calix, 2004).

In this study, ecomap was utilized to assess the interpersonal relationship of the respondents who are negatively-labeled. Eco-mapping revealed the extent of their relationship with their family, friends and teacher. This is a very useful instrument to find out if negative-labeling affected the social life of the respondents.

During the eco-mapping, the two respondents were assisted, guided and instructed what to do. The data collected were shown in Figure 4 and Figure 5 in the following pages. The lines have their specific meaning as indicated in the legend.

The respondents filled up the eco-map based on their actual and present of their relationship with the persons involved. They were oriented about the use of the different symbols to avoid errors. While they are answering, they are allowed to ask from the researchers and at the same time they are also asked. Three group of persons/persons were identified by the respondents, they are their family members, friends and their physics teacher. They were allowed to answer on their own to avoid intervention from other people. They also identified if who among their friends did label them negatively. 


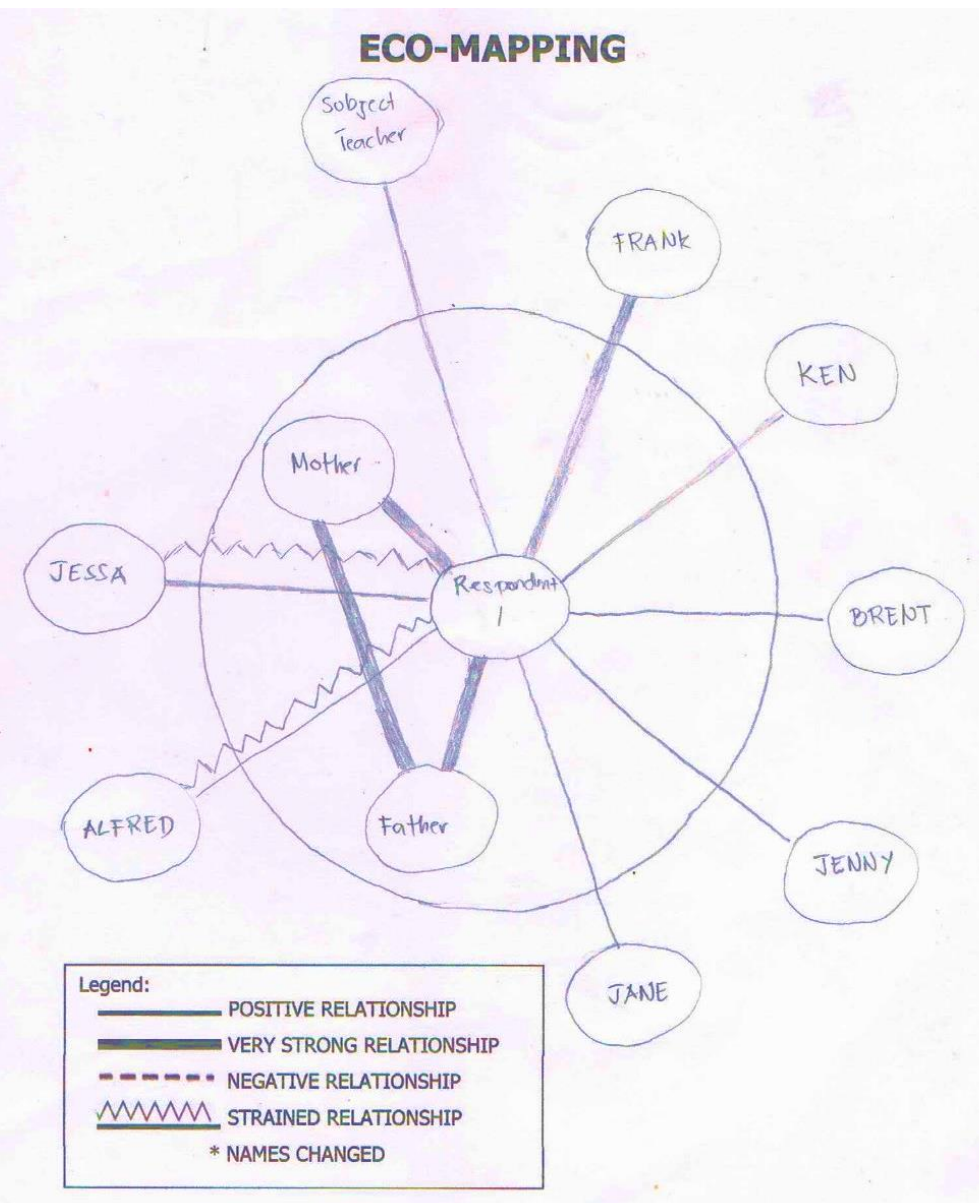

Figure 5. Ecomap of Respondent 1

Figure 5 shows the ecomap of the first respondent (John*). It is reflected on the result of his eco-map that he seemed to be tightly tied to his parents and he lives with a functional family. There appears that he had many peers who are close to him and a little conflict with his two classmates whose names are changed for ethical purposes. Those classmates with a strained relationship are the ones who negatively-labeled the respondent. His relationship with his teacher is positive and he has a very strong relationship with his best friend.

Different lines depicts a specific meaning based on the legend provided on the sheet. The respondent answered/filled-up the ecomap through his own free will so it is expected that the results are valid. After instructing him what to do, John* started filling-up the sheet. He was given the chance to clarify some things that he could not understand with the researchers. Prior to the ecomapping, John* was already interviewed so the researchers had the idea about him.

After doing the ecomap, John* was asked about his present relationships with the names he wrote and the lines he used. He said that he was negatively-labeled by some of his classmates as shown in Figure 5, two of his classmates with strained relationship. In the interview he stated if how he deal with the label given to him. He also revealed that having a strong relationship with his family is advantageous on his part as a student. His friends especially his best friend helped him to overcome the effects of negatively-labeling through their support and encouragement. 


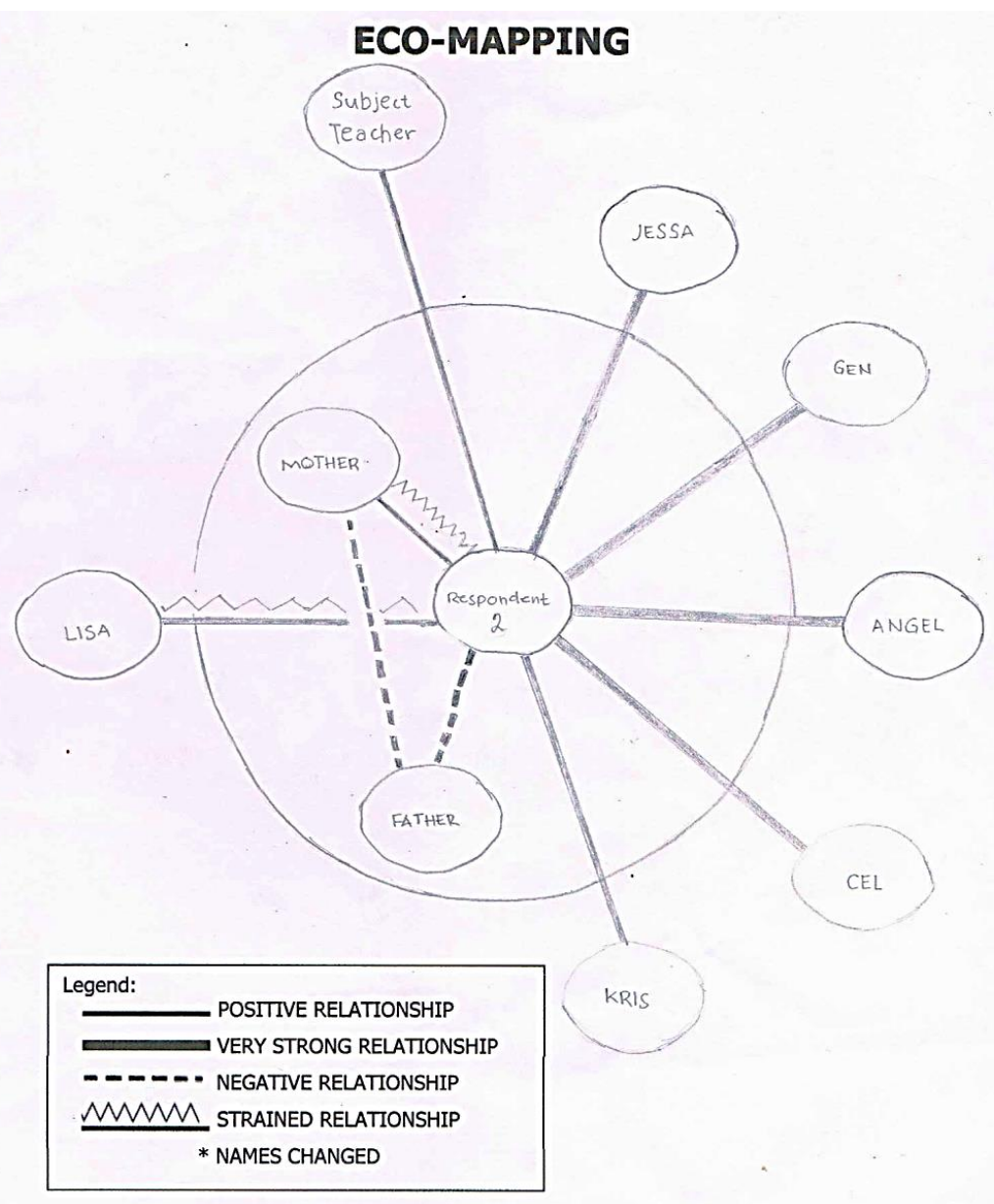

Figure 6. Ecomap of Respondent 2

Figure 6 shows the ecomap of the respondent 2 (Lea*). As observed on the data shown in the eco-map of Lea*, it is evident that she lives in a dysfunctional family. Knowing that she lives with a broken family, she has a negative relationship with her father, who is unknown to her, and a strained relationship with her mother. In terms of her relationship with her peers, she has a very strong connection with her four close friends and a positive relation with a friend. She revealed that one of her classmate labelled her negatively that is why they have a strained relationship. A positive relationship with her Physics teacher was shown.

The results show that the negatively-labeled students have a positive relationship towards their classmates and Physics teacher except for those classmates who labeled them. The results shown in Bronfenbrenner's Ecological Systems Theory and eco-maps suggest that having a functional family, John* seems to be contented of his present situation because his emotional, psychological, social, spiritual and moral needs are satisfied by his parents and relatives. Living in a dysfunctional family brings many disadvantages for a negatively-labeled student particularly in emotional, psychological and moral aspect because of inadequate support provided by his parents and relatives. Problem-saturated families can overwhelm education and other workers and erode relationships quickly, depleting resources, patience, and good will. Therefore, it is impossible to work with problem-saturated people in isolation without exhausting all resources (Aeby, Aeby and Boyd, 2007). In other words, family background 
affects the interpersonal relationships of negatively labeled students with peers and Physics teacher.

\section{Findings}

The study found out that negatively-labeled students have a positive relationship towards their classmates and Physics teacher except for those classmates who labeled them. These students experience a degraded self-esteem because of frequent humiliation and ridicule by their classmates inside a Physics class but dealing with labeling depends upon the personal outlook of the affected individual. It was also found out that family backgrounds may affect the interpersonal relationships of negatively labeled students with peers and Physics teacher.

\section{Conclusions}

The Bronfenbrenner's Ecological Systems Theory and ecomaps drawn by the subjects revealed having a functional family, the student seem to be contented of his present situation because his emotional, psychological, social, spiritual and moral needs are satisfied by his parents and relatives. It gives the individual a positive self-concept which means that they can address a more factual side of their life, such as knowing what they enjoy or how they tend to think. Living in a dysfunctional family brings many disadvantages for a negatively-labeled student particularly in emotional, psychological and moral aspect because of inadequate support provided by his parents and relatives.

In other words, family background affects the interpersonal relationships of negatively labeled students with peers and Physics teacher.

In the context of this study, the following themes emerged and were fused by the researchers to come up with a category: Negatively-labeled students experience a degraded self-esteem because of frequent humiliation and ridicule by their classmates inside a Physics class but dealing with labeling depends upon the personal outlook of the affected individual.

The findings of this study partly agrees with the term "self-fulfilling prophecy" (SFP) in the literature because some individuals may consider the negativity and turn it out into an opportunity for positivity. Some negatively-labeled students, like John*, may treat the stigma passively and accept a negative outlook of themselves but some, like Lea*, may take the challenge to overcome the stigma. Negatively-labeled students may counter what others expect of them through a positive self-outlook that can be justified through their improvement in their academic and scholastic performance in general.

\section{Implications}

\subsection{For Theory}

Negatively-labeled students, like John* and Lea*, have positive relationships towards their classmates and Physics teacher but tends to have strained relationships with their classmates who labeled them.

Negatively-labeled students experience a degraded self-esteem because of frequent humiliation and ridicule by their classmates inside a Physics class but dealing with labeling depends upon the personal outlook of the affected individual. Some students may remain passive towards those who label them but some may consider the negativity and turn it out into an opportunity for positivity. The emerging theme proposed by this study coincides with the words of Edelman (2006) which states that, "Labeling is the ultimate overgeneralization because it ignores the fact that people are a complex mixture of personal characteristics and 
behaviors, and we cannot be defined by just one or a few of these." Identifying the factors that contributed to an individual's negative experiences instead of focusing on the negativities caused by labeling gives the affected person the opportunity to learn from their own experiences and maintain a healthy outlook.

\subsection{For Practice}

As Labeling theory clearly illustrates, both the social and academic deviant, once labelled as such, are forced to carry these labels with them, performing the very behavior society expects of them, inevitably leading to confirmation bias (Ercole, 2009).

The term "self-fulfilling prophecy" (SFP) was coined in 1948 by Robert Merton (cited in Bearman \& Hedstrom, 2009) to describe "a false definition of the situation evoking a new behavior which makes the originally false conception come true". Teachers, as facilitators of knowledge, play a significant influence on their student's interpersonal relationship towards others inside or even outside the classroom. Hence, they must establish rapport with their students through wholesome communication and moral assistance. Teachers should not label students negatively for it produces a cascade of negative effects particularly in the student's self-esteem and self-perception. The teacher's influence should be used to incorporate morals and values to their students to reduce and gradually eliminate the rampant negative labeling among their students.

As an implication, the results derived from this study entitled "Labeling and Interpersonal Relationships of Negatively-Labeled Students in Physics" may not be true in other students especially those with different family background and classroom environment.

\section{Recommendations}

On the basis of the findings and conclusion derived from this study, the following recommendations are proposed:

1. Teachers are advised not to practice negative labeling on their students and establish positive relationship towards them to promote a positive classroom climate.

2. The results suggest that dealing with labeling depends upon the personal outlook of the affected individual therefore teachers are encouraged to guide their students and teach them not to ridicule and humiliate their fellow classmates.

3. The research results were limited to only two respondents. To better understand how labeling affects the interpersonal relationship of negatively-labeled students, similar researches should be conducted on a larger sampling population.

4. Future researchers should consider their research locale where negative labeling is present.

\section{Acknowledgments}

The authors, gratefully acknowledge the efforts of all the people who send their loving guidance and help in the realization of this paper. Heartfelt gratitude and genuine appreciation are extended to all of them who shared their time and knowledge for the completion of this study. This research is also supported by West Visayas State University.

\section{References}

[1] T. Aeby, V. Aeby and J. Boyd, "Ecomaps as visual tools for deconstructing reciprocal influences: Triage with disruptive students at an alternative school", School Community Journal, vol. 17, no. 2, (2007).

[2] R. Batan, "Understanding the impact of labeling among students on a physics classroom: A grounded theory approach (Undergraduate thesis)", Iloilo, Philippines, (2010). 
[3] J. Baumgartner, L. Burnett, C. DiCarlo and T. Buchanan, “An inquiry of children's social support networks using eco-maps", Child and Youth Care Forum, vol. 41, (2012), pp. 357-369.

[4] P. Bearman and P. Hedstrom, "The Oxford handbook of analytical sociology", Retrieved March 7, 2014 from http://users.ox.ac.uk/ $/$ sfos0060/prophecies.shtml, (2009).

[5] Birks \& Mills, "Essentials of grounded theory", Retrieved January 31, 2015 from http://www.sagepub.com/upm-data/36848_birks.pdf, (2010).

[6] T. Carpenter, V. Aeby and J. Boyd, "Ecomaps as visual tools for deconstructing reciprocal influences: Triage with disruptive students at an alternative school", Retrieved March 27, 2014 from http://files.eric.ed.gov/fulltext/EJ794784.pdf, (2007).

[7] K. Charmaz, "Constructing grounded theory: a practical guide through qualitative analysis", Thousand Oaks, California: SAGE Publications, Inc., (2006).

[8] A. Calix, "Is the ecomap a valid and reliable social work tool to measure social support?", (Master's thesis): Louisiana State University, Retrieved March 23, 2014 from http://etd.lsu.edu/docs/available/etd-04072004180134/unrestricted /Calix_thesis.pdf, (2004).

[9] L. Combrinck-Graham, "Children in family context (2nd ed.)", Retrieved March 30, 2014 from http://books.google.com.ph/books?id=RDFdAgAAQBAJ\&pg=PA64\&dq=thomlinson+ecomap\&hl=en\&sa= $\mathrm{X} \&$ ei=ubE7U_XnG8rhkAWppYG4Ag\&ved=0CCsQ6AEwAA\#v=onepage\&q=thomlinson\%20ecomap\&f=f alse. (2013).

[10] A. Davies, C. Elder and R. Gardner, "Conversation analysis", The handbook of applied linguistics. doi: 10.1002/9780470757000.ch10, (2008).

[11] S. Edelman, "Change Your Thinking: Overcoming Stress, Anxiety \& Depression, and Improve Your Life with Cognitive Behavior Therapy (CBT)", Australia: Da Capo Press, (2006).

[12] J. Ercole, "Labeling in the classroom: teacher expectations and their effects on students' academic potential", Retrieved March 22, 2014 from http://digitalcommons.uconn.edu/srhonors_theses, (2009).

[13] M. Forrester, "How to do conversation analysis: a brief guide", Department of Psychology, University of Kent, (2002).

[14] A. Gorra, "An analysis of the relationship between individuals' perceptions of privacy and mobile phone location data - a grounded theory study", Retrieved January 31, 2015 from http://www.leedsbeckett.ac.uk/inn/alic/agorra/3_Chapter3_Methodol gy_AndreaGorra.pdf, (2005).

[15] V. Kennedy, "Ecomaps", Retrieved April 1, 2014 from http://web.b.ebscohost.com/abstract?direct=true $\&$ profile $=$ ehost $\&$ scope $=$ site $\&$ authtype $=$ crawler $\&$ jrnl $=11775904 \& A N=56631301 \& \mathrm{~h}=$ madCX 8 UjwcIHehNG YVwHOY29vCVjT5QU0hnGtLArOB7ISz9S2w9pW4c1MCcYv4ggyF4zB\%2bv3woksEpurrBEZKg\%3d\% $3 \mathrm{~d} \& \mathrm{crl}=\mathrm{c},(\mathbf{2 0 1 0})$.

[16] H. Knoff, "The assessment of child and adolescent personality", Retrieved April 1, 2014 from http://books.google.com.ph/books?id=DxLjCB5FIVoC\&pg=PA408\&dq=ecomap\&hl=en\&sa=X\&ei=0LM7 U9niHsblkAWzjoGYAQ\&ved=0CDoQ6AEwAjgK\#v=onepage\&q=ecomap\&f=false, (2003).

[17] M. A. Mattaini and J. G. Daley, "Should social workers rely on genograms and ecomaps?", In Thyer, B.A. (Ed.), Controversial issues in social work practice, Needham Heights, MA: Allyn and Bacon, (1997), pp. 217, 231.

[18] K. McCormick, S. Stricklin, T. Nowak and B. Rous, "Young exceptional children", doi: 10.1177/1096250607311932, (2008).

[19] S. A. McLeod, "Attitude measurement", Retrieved March 25, 2014 from http://www.simplypsychology.org/attitude-measurement.html, (2009).

[20] R. McWilliam, "Working with families of young children with special needs", Guilford press, (2010), pp. 1322.

[21] F. Myrick and D. Walker, "Qualitative health research", Retrieved March 22, 2014 from http://qhr.sagepub.com/content/16/4/547.

[22] D. Paquette and J. Ryan, "Bronfenbrenner's ecological systems theory", Retrieved January 28, 2015 from http://www.floridahealth.gov/alternatesites/cms-kids/providers/early_steps/training/documents/ bronfenbrenners_ecological.pdf, (2001).

[23] A. Perakyla, "The blackwell encyclopedia of sociology online: Conversation analysis", Retrieved March 23, 2014 from http://blogs.helsinki.fi/perakyla/files/ 2008/10/conversationanalysis_0811.pdf, (2008).

[24] Qualitative Research Design (2005). Retrieved March 29, 2014 from http://researchrundowns.wordpress.com/qual/qualitative-research-design/.

[25] R. C. Rist, "On understanding the processes of schooling: The contributions of labeling theory: Exploring education ( $2^{\text {nd }}$ ed.)", Allyn \& Bacon, (1977), 2001, pp. 149-157.

[26] L. Roundy, "Bronfenbrenner's ecological systems theory of development: Definition \& examples", Retrieved January 28, 2015 from http://education-portal.com/academy/lesson/bronfenbrenners-ecological-systemstheory-of-development-definition-examples.html, (2014). 
[27] J. Sidnell, "Conversation analysis comparative perspective", Retrieved March 28, 2014 from http://www.cambridge.org/us/academic/subjects/languages-linguistics/sociolinguistics/conversation-analysiscomparative-perspectives, (2012).

[28] J. Sternke, "Self-concept and self-esteem in adolescents with learning disabilities", (Research Paper). University of Wisconsin-Stout, (2010).

[29] University of Southern California (2014). Organizing your social sciences research paper. Retrieved March 25, 2014 from http://libguides.usc.edu/content. php?pid=83009\&sid=615866.

[30] R. Vodde and M. Giddings, "The field system eco-map: A tool for conceptualizing practicum experiences", Journal of Teaching in Social work, doi: 10.1300/J067v20n03_05, (2008), pp. 41-61.

[31] A. Woolfolk, "Educational psychology (pp 112-113) (11th ed.)", Jurong, Singapore: Pearson Education, Inc., (2010).

[32] C. Zastrow, "The practice of social work: a comprehensive worktext", Retrieved April 1, 2014 from http://books.google.com.ph/books?id=FdbH_2bwpDgC\&printsec=frontcover\&dq=The+Practice+of+Social+ Work:+A+Comprehensive+Worktext\&hl=en \&sa=X\&ei=67U7UaSNMzRkwWG3oG4BA\&ved=0CCsQ6AE

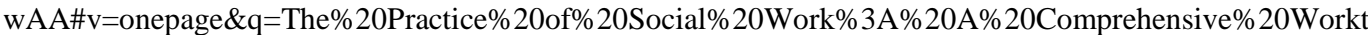
ext\&f=false, (2009). 